\title{
THE APPLICATION OF INTENSIVE AND EXTENSIVE TASK-BASED FORM-FOCUSED VS. TASK-SUPPORTED INSTRUCTION ON EFL LEARNERS' WRITTEN TASK ACCURACY
}

\author{
Asghar Salimi ${ }^{1 *}$, Sevda Sadighi Rad ${ }^{2}$ \\ ${ }^{1}$ Assistant Prof. Dr., University of Maraghe, Iran, asgharsalimi356@gmail.com \\ ${ }^{2}$ MA.in TESOL, University of Maraghe, Iran, sevda sadighirad@yahoo.com \\ ${ }^{*}$ Corresponding author
}

\begin{abstract}
Some second language acquisition researchers argue that the way the instructors provide form focused instructions is of great significance in SLA development. The aim of the present study was to investigate whether intensive and extensive form-focused instruction would be useful for Iranian EFL learners' written task accuracy. To accomplish the purpose of this quasi-experimental study, 60 female elementary learners in four intact classes were randomly selected as, the control group $(n=15)$, intensive focus on form group $(n=15)$, extensive focus on form group $(n=15)$, and traditional (PPP) group $(n=15)$. All groups participated in 17 sessions of telling reading summary task. The intensive group received feedback on simple past tense errors only. The extensive group received feedback on all kinds of errors including grammatical, pronunciation and lexical errors. The PPP group was based on traditional method of presenting, practicing and producing and the control group didn't receive any feedback on errors. To collect written data from the participants, a narrative task was employed. The written data was quantified regarding the accuracy measure introduced by Ellis (2012). The results of statistical analysis revealed that all form focused groups significantly outperformed the control group. It can also be concluded that the intensive focus on form was more effective in improving Iranian learners' written accuracy.
\end{abstract}

Keywords: focus on form, focus on forms, intensive focus on form, extensive focus on form, accuracy

\section{INTRODUCTION}

When learners receive corrective feedback they can notice the gap that exists between their original output and the target structure. Form-focused instruction can provide opportunities for noticing those gaps. These statements are in line with the theoretical debates on the importance of corrective feedback (Schmidt, 1990; Swain, 1995). The present study focuses on the effects of intensive, extensive and traditional PPP formfocused instruction on EFL learners' written task performance in terms of accuracy. Most of the existing studies in this regard have investigated the effectiveness of focus on form but the effects of degree of attention to form have rarely been explored in SLA literature. The present study, thus, is going to contribute to existing literature on the topic first. The findings of the present study will contribute to the literature of SAL theoretically as well as practice of language teaching in language classes. 


\section{LITERATURE REVIEW}

Corrective feedback and its effects have been the matter of discussion and research in recent years. Long, 1996 considers corrective feedback as facilitator in ESL development, because through negotiation of meaning it can provide learners with opportunities to notice the differences between output and input.

Some researchers (e.g., Krashen, 1985; Kepner, 1991; Sheppard, 1992; Truscott, 1996, 2007) believe that grammar correction is not effective in development of second language written accuracy. Some researchers had extreme views. Krashen (1985) indicated that since corrective feedback disrupts the flow of discourse and communication it is harmful. In 1996 Truscott's article questioned the effectiveness of corrective feedback in improving learners' written accuracy. He asserted that grammar correction is not only useless in writing classes but also harmful. Ferris (1999) didn't support Truscott's view and believed that as the research results proved effective error correction to be helpful, it could not be completely abandoned. Truscott (2007) once more concluded that correction only has an unsubstantial harmful effect on the learners' accuracy; so it is a misstep.

In contrast, some other researchers (e.g., Chandler, 2003; Bichener, et al, 2005; Sheen, 2007; Bitchener and Knoch, 2008; Ellis, 1999, 2003, 1994, 2005, 2008; Rahimpour and Salimi, 2010; Khatib and Alizedeh, 2012) claim that CF is valuable and effective. Since 1990 the Noticing Hypothesis (Schmidt, 1990, 2001) has been generating experimental studies. It states that if input is not consciously noticed it won't become intake. Many people believe that, students learn things when they pay attention to them. Others think that the hypothesis lacks empirical support. Focus on form is based on this cognitive psychological theory which is against Krashen's input hypothesis. Swain $(1995,1998)$ highlights the role of output. He claims that when students attempt to produce the target language, they are encouraged to notice their linguistic problems as well, which helps them to internalize linguistic knowledge (Swain, 1995, p.126).

Ellis (2001a: 1), defines form focused instruction as any planned or incidental instructional activity to induce language learners attention to linguistic form.

According to Long (1991), there is a distinction between focus on form and focus on forms, as the former means attending to problems in all aspects of TL when learners try to convey massages and the latter refers to pre-selecting isolated TL features, presenting them systematically and practicing those features. According to Ellis (2012) focus on form is the approach which requires an effort to make incidental acquisition during communicative activities through instruction by drawing learners' attention to linguistic features (p. 272). Chandler (2003) examined the effects of different types of CF on ESL learners' written accuracy and fluency. In this study all types of corrective feedback proved to be effective and intensive group with greater attention to form achieved the highest rate of accuracy. According to Karimi and Fotovatnia (2010) cited in Alimohammadi and Nejadansari (2014) written corrective feedback is of broad pedagogical value, and both focused and Unfocused Corrective Feedback can equally result in grammatical written accuracy.

Degree of attention to form as it is mentioned in Ellis (2003) affects written production accuracy differently. He defines Extensive focus on form as drawing learners' attention to whole range of linguistic items and Intensive focus on form as drawing learners' attention to specific grammatical linguistic item again and again. Doughty and Varela (1998) studied the effectiveness corrective feedback in a content-based ESL classroom over four weeks. Past time references, simple past and conditionals were selected as the target form. They used recasting, to correct only errors concerning past time reference. The results revealed that there were significant positive developmental effects on experimental group's inter-language, and no progress in control group. Rouhi \& Samiei (2010) studied the effectiveness of focused and unfocused indirect feedback where the focus was on the use of simple past tense in second language writing. They conducted the study with three groups of students, (focused group, unfocused group, and control group). In this study they came up with no statistically significant difference among the three groups. In a study carried out by Farrokhi and Sattarpour (2012) focused focus on form proved to be more effective on the students' grammatical accuracy than unfocused focus on form.

Rahimpour, Salimi and Farrokhi (2012) investigated the effects of intensive and extensive form-focused instructions on 40 pre-intermediate EFL learners' written accuracy. The results of this study revealed that learners who received intensive form-focused instruction outperformed those who received extensive fromfocused instruction.

Farahani and Sarkhosh (2012) investigated the effect of different formats of textual enhancement on 101 female EFL learners' intake of English conditional type II. The results indicated that intensive underlining format was more effective to induce the intake of target form. 
Saeb (2013) studied the effects of focused and unfocused written corrective feedback on 79 female EFL learners' grammatical accuracy. She found written corrective feedback effective and improving in this regard but the degree of attention to form didn't prove to have differential effect for this purpose.

The incentive to this study was found in the inconsistent results; since some researchers believed intensive error correction to be more effective in enhancing learners' grammatical accuracy (Farrokhi and Sattarpour (2012), Farahani and Sarkhosh (2012)) and some others found that learners' benefit equally from both intensive and extensive types of error correction (Rouhi \& Samiei (2010), Saeb (2013)). On the other hand most researchers used tests as means of data collection and there seems to be a gap in literature regarding the effects of form-focused instruction on learners' task performance. Based on these incentives, the present study aimed to investigate the implications of three models of form-focused instruction strategies on EFL learners' accuracy in performing written tasks.

\section{RESEARCH QUESTION AND HYPOTHESES}

What are the effects of intensive and extensive form-focused task-based vs. task supported instruction on EFL learners' written task accuracy?

H1. There are significant differences among the accuracy of L2 learners in all three models of FOF instruction.

H2. Intensive FOF would lead to more accuracy than extensive FOF, PPP and CLT.

\section{METHODOLOGY}

\subsection{Participants}

In this study 60 female elementary EFL learners in the 15-23 age range of Chitsazan Language Institute (CLI), East Azerbaijan, Iran were selected as the participants. Their proficiency in English was at the same level due to their same language learning experience in this institute. They were homogeneous on the basis of placement test and prior course completion and final exam scores of their previous term. Three intact classes were assigned to the three experimental groups randomly: focused error correction $(n=15)$, unfocused error correction ( $n=15)$ and PPP $(n=15)$. The fourth class was assigned to a control group $(n=15)$.

\section{2. Materials and Tasks}

The instructional material in this institute was a communicative and meaning-based one which was planned and managed by Research and Development group of Chitsazan Language Institute. The focus of the textbook covered in the course was on grammar and vocabulary. It provided different opportunities for learners to take part in communicative activities (Rise and Shine 3, compiled by: Mahmoud Reza Chitsazan, Seyyedeh Faezeh Yousefi, Hamed Kazem Zadeh, 2014). The material for data collection was a pictorial narrative written task which was taken from the sample examinations in Cambridge University Press (2007). On the basis of given instruction the learners were required to narrate the story of the pictures in the past tense.

\section{3. Procedure}

In this quasi-experimental study the learners were divided into three experimental groups of intensive, extensive, PPP, and a control group. They received treatment for one semester (17 sessions) while giving oral summaries of the stories in their book every session. The participants in intensive group were provided with focused oral corrective feedback on errors in the use of past tense only and the extensive group received unfocused oral corrective feedback on lexical, grammatical and pronunciation errors. For example when a student said: "He go shopping with bus that day." in the intensive group, correction was provided for incorrect tense use of the verb "go" only and there was no correction for erroneous use of proposition" with". But a learner in extensive group received correction for all errors including even pronunciation errors. All corrections were in the form of recast which is characterized as the immediate implicit correction after learner's erroneous utterance. The participants in PPP group had the traditional treatment of presenting, practicing and producing the target forms and the participants in control group focused on meaning and didn't receive any kind of correction on their potential errors. The last session data was collected by means of the pictorial task described in previous section. It was measured in terms of an accuracy measure introduced by R.Ellis (2012, p 207) as the percentage of correct use of the specific grammatical feature in obligatory occasions. 


\section{Data analysis}

In order to analyze the collected data in this study, the Statistical Package for Social Sciences (SPSS), was employed.

Table 1 shows the results of descriptive statistics for the accuracy of intensive and extensive form-focused groups' written task performance.

Table 1 .Descriptive Statistics for the Accuracy of Intensive and Extensive FOF Groups' Written Task Performance

\begin{tabular}{|cc|c|c|c|c|}
\hline & Method & $\mathrm{N}$ & Mean & Std. Deviation & Std. Error Mean \\
\hline Accuracy Scores & Extensive & 15 & 74.9493 & 13.48339 & 3.48140 \\
\cline { 2 - 6 } & Intensive & 15 & 85.3527 & 12.24476 & 3.16158 \\
\hline
\end{tabular}

According to the results presented in table 1 , learners who had received intensive form focused instruction outperformed those learners who had received extensive form focused instruction.

In order to see whether the differences between the means of two groups are significant or not an independent t-test was run.

Table 2 shows the result of the analysis.

Table 2. Independent Sample T-TEST for the Accuracy Of Intensive and Extensive FOF Groups' Written Task Performance

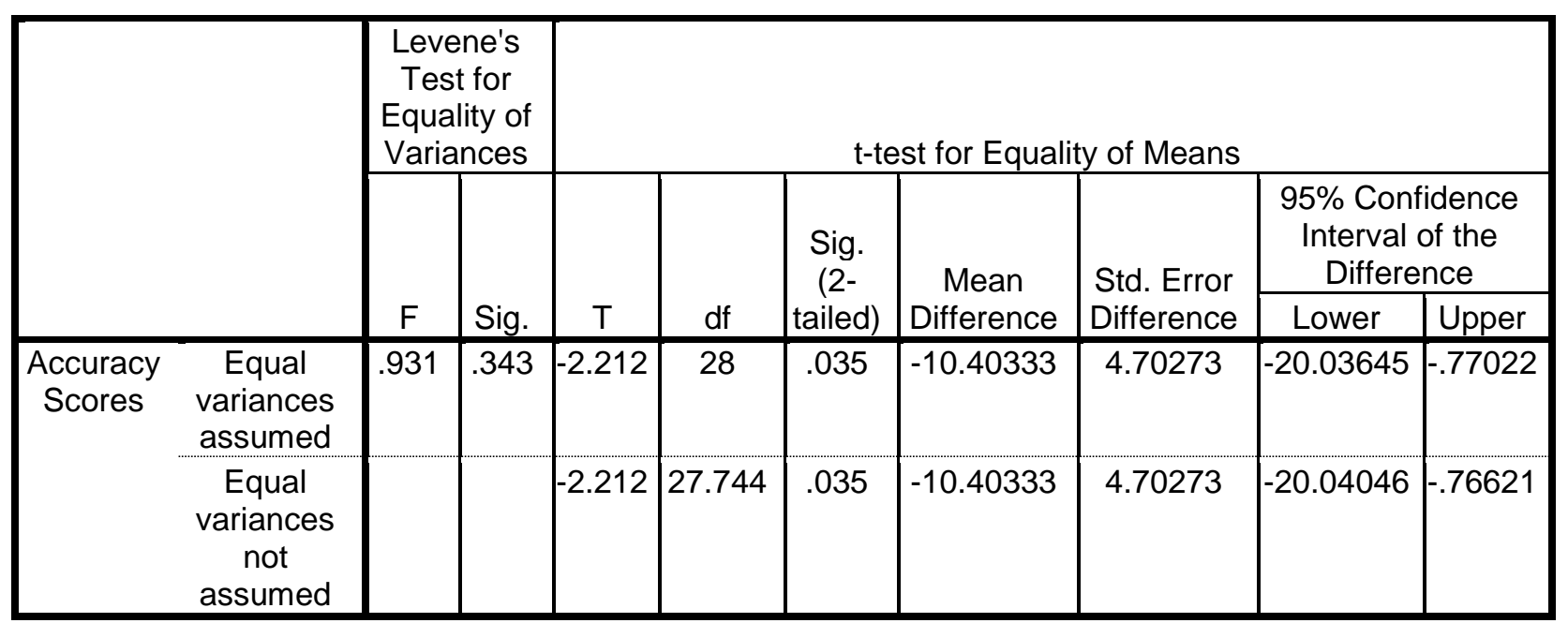

According to the results of the analysis there is a significant difference between the accuracy of two groups. In order to see whether the difference among the means of four groups is significant, a one way ANOVA was run.

The descriptive statistics of means for the accuracy of four groups in written narrative task are presented in table 3. 
Table 3. Descriptive Statistics of Means for the Accuracy of Intensive, Extensive, PPP and CLT Groups' Written Task Performance

\begin{tabular}{|c|c|c|c|c|c|c|c|c|}
\hline & \multirow[b]{2}{*}{$\mathrm{N}$} & \multirow[b]{2}{*}{ Mean } & \multirow{2}{*}{$\begin{array}{c}\text { Std. } \\
\text { Deviation }\end{array}$} & \multirow[b]{2}{*}{ Std. Error } & \multicolumn{2}{|c|}{$\begin{array}{l}\text { 95\% Confidence Interval for } \\
\text { Mean }\end{array}$} & \multirow[b]{2}{*}{ Minimum } & \multirow[b]{2}{*}{ Maximum } \\
\hline & & & & & Lower Bound & Upper Bound & & \\
\hline Extensive & 15 & 74.9493 & 13.48339 & 3.48140 & 67.4825 & 82.4162 & 50.00 & 92.85 \\
\hline Intensive & 15 & 85.3527 & 12.24476 & 3.16158 & 78.5717 & 92.1336 & 57.14 & 100.00 \\
\hline CLT & 15 & 41.5947 & 23.72611 & 6.12606 & 28.4556 & 54.7338 & .00 & 71.42 \\
\hline PPP & 15 & 59.4027 & 20.10680 & 5.19155 & 48.2679 & 70.5374 & 22.22 & 88.88 \\
\hline Total & 60 & 65.3248 & 24.20405 & 3.12473 & 59.0723 & 71.5774 & .00 & 100.00 \\
\hline
\end{tabular}

The results of the analysis revealed that the learners in intensive FoF group performed better than the learners in extensive FoF group; and learners in PPP and CLT groups had respectively weaker performances.

Table 4 shows the results of ANOVA for comparing the means of intensive, extensive, PPP and CLT groups.

Table 4. The Results of ANOVA for the Means of Four Groups

\begin{tabular}{|c|c|c|c|c|c|}
\hline & Sum of Squares & Df & Mean Square & F & Sig. \\
\hline Between Groups & 16379.070 & 3 & 5459.690 & 16.813 & .000 \\
Within Groups & 18185.265 & 56 & 324.737 & & \\
Total & 34564.334 & 59 & & & \\
\hline
\end{tabular}

According to the result of the statistical analysis in table 4, there are significant differences among the means of four groups.

For the purpose of the multiple comparisons of the means, the Post Hoc LSD Test was employed.

The results are presented in table 5.

Table 5. LSD Multiple Comparisons of the Means of Four Groups

\begin{tabular}{|cc|c|c|c|c|c|}
\hline \multirow{2}{*}{$\begin{array}{c}\text { (I) Proficiency \& } \\
\text { Focus }\end{array}$} & $\begin{array}{c}\text { Mean } \\
\text { (J) Proficiency \& }\end{array}$ & $\begin{array}{c}\text { Difference (I- } \\
\text { J }\end{array}$ & & & \multicolumn{2}{|c|}{$95 \%$ Confidence Interval } \\
\cline { 6 - 7 } & Focus & Std. Error & Sig. & Lower Bound & $\begin{array}{c}\text { Upper } \\
\text { Bound }\end{array}$ \\
\hline Extensive & Intensive & -10.40333 & 6.58014 & .120 & -23.5849 & 2.7783 \\
& CLT & $33.35467^{*}$ & 6.58014 & .000 & 20.1731 & 46.5363 \\
& PPP & $15.54667^{*}$ & 6.58014 & .022 & 2.3651 & 28.7283 \\
\hline Intensive & Extensive & 10.40333 & 6.58014 & .120 & -2.7783 & 23.5849 \\
& CLT & $43.75800^{*}$ & 6.58014 & .000 & 30.5764 & 56.9396 \\
& PPP & $25.95000^{*}$ & 6.58014 & .000 & 12.7684 & 39.1316 \\
\hline CLT & Extensive & $-33.35467^{*}$ & 6.58014 & .000 & -46.5363 & -20.1731 \\
& Intensive & $-43.75800^{*}$ & 6.58014 & .000 & -56.9396 & -30.5764 \\
& PPP & $-17.80800^{*}$ & 6.58014 & .009 & -30.9896 & -4.6264 \\
\hline PPP & Extensive & $-15.54667^{*}$ & 6.58014 & .022 & -28.7283 & -2.3651 \\
& Intensive & $-25.95000^{*}$ & 6.58014 & .000 & -39.1316 & -12.7684 \\
& CLT & $17.80800^{*}$ & 6.58014 & .009 & 4.6264 & 30.9896 \\
\hline
\end{tabular}

${ }^{*}$. The mean difference is significant at the 0.05 level. 
According to the results of the analysis, a glance at the table reveals that there are significant differences among the performances of four groups. The learners who received intensive CF outperformed all other groups although the difference between intensive and extensive group was not statistically significant. PPP group also outperformed CLT group this means that task-supported activities can be of importance in language classes alongside task-based activities.

\section{DISCUSSION}

Regarding the first hypothesis claiming that there are significant differences among accuracy of L2 learners in all three models of form focused instruction strategies, the results of statistical analysis of applying OneWay ANOVA revealed that the difference among the groups was significant and intensive group led to the production of more accurate language. For multiple analysis, the results of LSD test revealed that there was significant difference among intensive, CLT and PPP groups. All intensive, extensive and PPP groups led to more accurate language than CLT group. The findings are in line with the findings of Chandler(2003), Bichener, et al,( 2005), Sheen(2007), Bitchener and Knoch(2008), Ellis(1999, 2003, 1994, 2005, 2008), Rahimpour and Salimi(2010), Karimi and Fotovatnia (2010) and Khatib and Alizedeh(2012) on the great pedagogical value of CF. However they were odd with the findings of Krashen(1985), Kepner(1991), Sheppard(1992) and Truscott(1996,2007) who didn't believe in the effectiveness of grammar correction in development of second language learners' written accuracy.

This higher rate of accuracy in intensive, extensive and PPP groups than CLT group suggests the inclusion of task based (Focus on Form) and task supported (Focus on Forms) activities in EFL grammar classes. In line with the argumentation of Ellis on the existence of different versions of TBLT, (Ellis, 2012, P 197) this paper also supports the use of task based along with traditionally-oriented task supported activities.

Regarding the second hypothesis claiming that Intensive FoF would lead to more accuracy than extensive FoF and PPP, the results of statistical analysis (Independent T test) revealed that there was no significant difference between the accuracy of learners in intensive and extensive group. However, learners in intensive group outperformed the learners who received extensive FoF. Therefor intensive focus on form was more effective than extensive focus on form. The findings of the study are in line with the findings of Chandler (2003), Farrokhi and Sattarpour (2012), Farahani and Sarkhosh (2012) and Rahimpour et al. (2012) who found that intensive groups achieved highest rate of accuracy in their studies. However the findings of the present study ran against the findings of Saeb (2013) and Rouhi \& Samiei (2010) who found that the degree of attention to form in written CF didn't have differential effect on learners' grammatical accuracy. This higher rate of accuracy in intensive focus on form can be attributed to the opportunity to process language deeply in intensive focus on form due to its repetition and frequency.

\section{PEDAGOGICAL IMPLICATIONS AND CONCLUSION}

The findings of the present study might carry significant implications for SLA as well as the practice of language teaching. Feedback can be considered as the inevitable part of any teaching and learning context. Understanding the nature of functioning of the noticing and attention will help SLA researchers to discover more about its functioning and role in learning. Task designers and textbook writers will benefit the findings of the study by assigning some roles for conscious learning in textbooks and exercises. Teachers will also benefit the findings of the paper in choosing the type of corrective feedback according to the effectiveness of each type. They can also succeed in developing the learners' accuracy by combining task based along with task-supported activities. 


\section{Appendix}

$\infty$

Tell the story

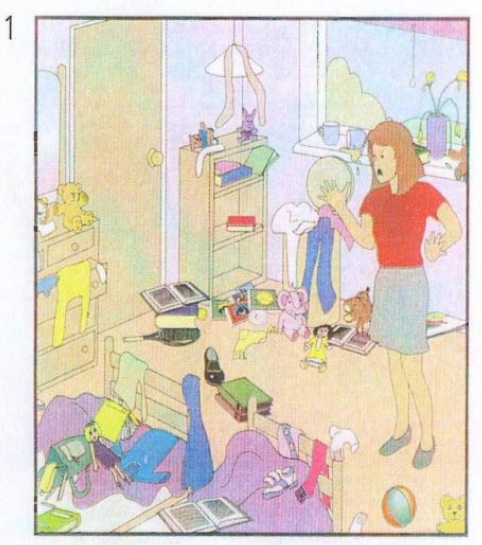

Examiner's and Candidate's copy

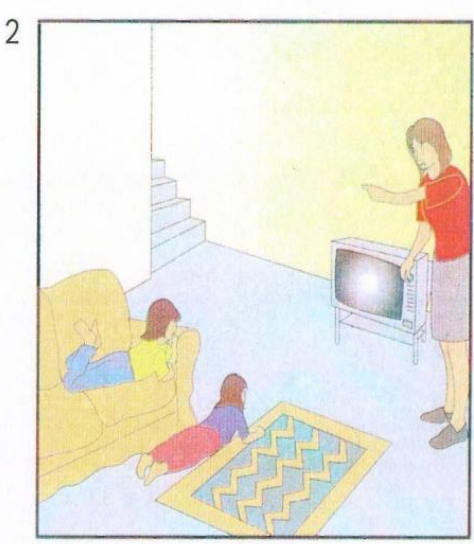

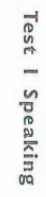
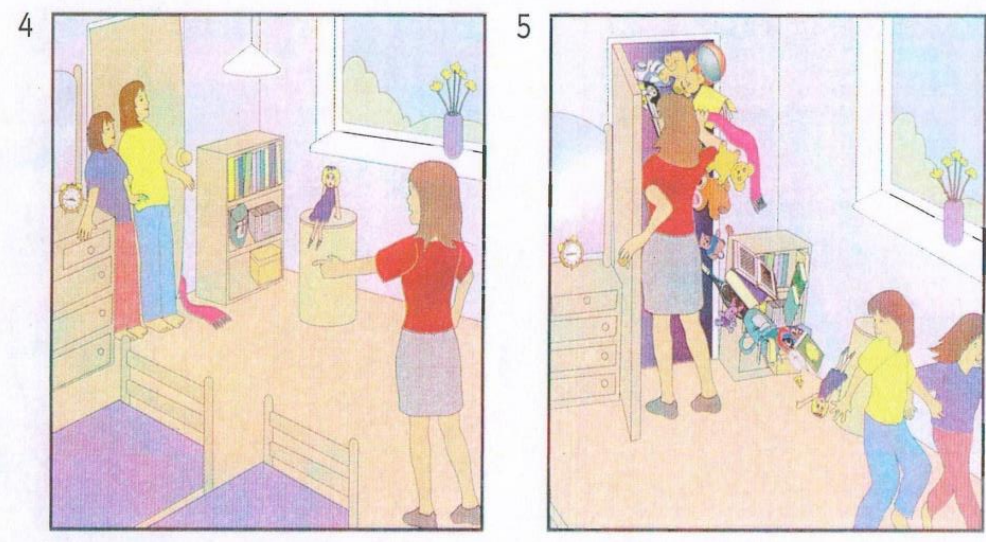

$8 \ll$

Look at the pictures and narrate the story:

One day the mother went into children's room 


\section{REFERENCE LIST}

Bichener, J., Young, Y. and Cameron, D. (2005). The effect of different types of corrective feedback on ESL student writing. Journal of Second Language Writing, 14, 191-205.

Bitchener, J. and Knoch, U. (2008). The value of written corrective feedback for migrant and international students. Language Teaching Research 12 (3), 409-431.

Chandler, J. (2003). The Efficacy of Various Kinds of Error Feedback for Improvement in the Accuracy and Fluency of L2 Student Writing. Journal of Second Language Writing, 12, 267-296.

http://dx.doi.org/10.1016/S10603743(03)00038-9

Doughty, C. and Varela, E. (1998). Communicative focus on form. In C. Doughty \& J. Williams (Eds.), Focus on form in classroom second language acquisition (pp. 114-138). Cambridge: Cambridge University Press.

Ellis, R. (1994). The study of second language acquisition. Oxford: Oxford University Press.

Ellis, R. (1999). Input-based approaches to teaching grammar: A review of classroom-oriented research. Annual Review of Applied Linguistics, 19, 64-80.

Ellis, R. (2001a). Investigating form-focused instruction. Language Learning 51, Supplement 1, 1-46.

Ellis, R. (2003). Task-based language learning and teaching. Oxford: Oxford University Press.

Ellis, R. (Ed.) (2005). Planning and task performance in a second language. Amsterdam: John Benjamins.

Ellis, R. (2008). Typology of written corrective feedback. ELT Journal; doi: 10. 1093/elt/ccn023.

Ellis, R. (2012). Language teaching research and language pedagogy. Wiley-Blackwell, Sussex.

Farahani, A. K. and Sarkhosh, M. (2012). Do different textual enhancement formats have different effects on the intake of English subjunctive mood? Theory and Practice in Language Studies, 2(4), 688-698.

Farrokhi, F. and Sattarpour, S. (2011). The Effects of Focused and Unfocused Written Corrective Feedback on Grammatical Accuracy of Iranian EFL Learners. Theory and Practice in Language Studies, 1(12), 1797-1803.

Ferris, D. (1999). The case for grammar correction in L2 writing classes: a response to Truscott (1996). Journal of Second Language Writing, 8, 1-10.

Karimi, M. and Fotovatnia, Z. (2012). The Effects of focused vs. Unfocused Written Teacher Correction on the Grammatical Accuracy of Iranian EFL Undergraduates. The Asian EFL journal, 62, 117-141.

Kepner, C. G. (1991). An experiment in the relationship of types of written feedback to the development of second language writing skills. Modern Language Journal, 75, 305-313.

Khatib, M. and Alizadeh, M. (2012). Output tasks, noticing, and learning: Teaching English past tense to Iranian EFL learners. English Language Teaching, 5(4), 173-186.

Krashen, S.D. (1985). The input hypothesis. London: Longman.

Long, M.H., (1991). Focus on form: A design feature in language teaching methodology. In: K. de Bot, R. Grinberg \& C. kramsch, (Eds.), Foreign Language Research in Crosscultural Perspective (pp: 39-52). Amsterdam: John Benjamins.

Long, M. H. (1996). The role of linguistic environment in second language acquisition. In: W. C. Ritchie \& T. K. Bhatia (Eds.), Handbook of second language acquisition (pp. 413-468). New York:Academic Press.

Rahimpour, M. and Salimi, A. (2010). The impact of explicit instruction on foreign language learners' performance. Procedia- Social and Behavioral Sciences, 2, 1740-1746.

Rahimpour, M. , Salimi, A. and Farrokhi, F. (2012). The Effect of Intensive and Extensive Focus on Form on EFL Learners' Written Accuracy. Theory and Practice in Language Studies, 2(11), 2277-2283.

Rouhi, A. and Samiei, M. (2010). The Effects of Focused and Unfocused indirect Written Corrective Feedback on Grammatical Accuracy of Iranian EFL Learner. Social Science, 5(6), 481-485.

Saeb, F. (2014). The Effects of Focused and Unfocused Written Corrective Feedback on The Grammatical Accuracy of Beginner EFL Learners. International Journal of Applied Linguistics \& English Literature, 
3(2), 22-26.

Schmidt, R. (1990). The Role of Consciousness in Second Language Learning. Applied Linguistics, 11, 129158.

Schmidt, R. (2001). Attention. In: P. Robinson, (Ed.), Cognition and second language instruction (pp: 3-32). Cambridge: Cambridge University Press.

Sheen, Y. (2007). The Effect of Focused Written Corrective Feedback and Language Aptitude on ESL Learners' Acquisition of Articles. TESOL Quarterly, 41, 255-283.

Sheppard, K. (1992). Two feedback types: do they make a difference? RELC Journal, 23, 103- 110.

Swain, M. (1995). Three Functions of Output in Second Language Learning. In: G.Cook \& B. Seidhofer (Eds.), For H.G. Widdowson: Principles and practice in the study of language (pp. 125-144). Oxford: Oxford University Press.

Swain, M. (1998). Focus on form through conscious reflection. In: C. Doughty \& J. Williams, (Eds.), Focus on form in classroom second language acquisition (pp. 64-81). Cambridge: Cambridge University Press.

Truscott, J. (1996). The Case Against Grammar Correction in L2 Writing Classes. Language Learning, 46, 327-369.

http://dx.doi.org/10.1111/j.1467-1770.1996.tb01238.x

Truscott, J. (2007). The Effect of Error Correction on Learners' Ability to Write Accurately. Journal of Second Language Writing, 16, 255-272.

http://dx.doi.org/10.1016/j.js/w.2007.06.003 